\title{
Antitrypanosomal activity of aloin and its derivatives against Trypanosoma congolense field isolate
}

\author{
Yitagesu Tewabe ${ }^{1}$, Daniel Bisrat ${ }^{1},{\text { Getachew } \text { Terefe }^{2} \text { and Kaleab Asres }}^{{ }^{*}}$
}

\begin{abstract}
Background: There is an urgent need for the development of new, cheap, safe and highly effective drugs against African trypanosomiasis that affects both man and livestock in sub-Saharan Africa including Ethiopia. In the present study the exudate of Aloe gilbertii, an endemic Aloe species of Ethiopia, aloin, aloe-emodin and rhein were tested for their in vitro and in vivo antitrypanosomal activities against Trypanosoma congolense field isolate. Aloin was prepared from the leaf exudate of A. gilbertii by acid catalyzed hydrolysis. Aloe-emodin was obtained by oxidative hydrolysis of aloin, while rhein was subsequently derived from aloe-emodin by oxidation. In vitro trypanocidal activity tests were conducted on parasites obtained from infected mice, while mice infected with $T$. congolense were used to evaluate in vivo antitrypanosomal activity of the test substances.

Results: Results of the study showed that all the test substances arrested parasites motility at effective concentration of $4.0 \mathrm{mg} / \mathrm{ml}$ within an incubation period ranging from 15 to $40 \mathrm{~min}$. Moreover, the same concentration of the test substances caused loss of infectivity of the parasites to mice during 30 days observation period. Among the tested substances, rhein showed superior activity with minimum inhibitory concentration (MIC) of $0.4 \mathrm{mg} / \mathrm{ml}$. No adverse reactions were observed when the test substances were administered at a dose of $2000 \mathrm{mg} / \mathrm{kg}$. Rhein at doses of 200 and $400 \mathrm{mg} / \mathrm{kg}$, and the exudate, aloin and aloe-emodin at a dose of $400 \mathrm{mg} / \mathrm{kg}$ reduced the level of parasitaemia significantly $(P<0.05)$ and improved anaemia.

Conclusion: The results obtained in this investigation indicate that aloin and its derivatives particularly rhein have the potential to be used as a scaffold for the development of safe and cost effective antitrypanosomal drugs that can be useful in the continuing fight against African trypanosomiasis.
\end{abstract}

Keywords: African trypanosomiasis, Aloe gilbertii, Aloin, Aloe-emodin, Rhein, Antitrypanosomal activities, Trypanosoma congolense

\section{Background}

Trypanosomiasis is a potentially fatal human and animal disease caused by the parasitic protozoa of the genus Trypanosoma. These diseases occur in tropical Africa and South America [1,2]. Human African trypanosomiasis (HAT) or sleeping sickness is a severe fly-borne disease caused by protozoa of the species Trypanosoma brucei rhodesiense and T.b. gambiense. This disease was first described by the late 1800 s and early 1900 s even if it had probably existed in Africa many centuries before.

\footnotetext{
* Correspondence: kaleab.asres@aau.edu.et

${ }^{1}$ Department of Pharmaceutical Chemistry and Pharmacognosy, School of

Pharmacy, Addis Ababa University, Addis Ababa, Ethiopia

Full list of author information is available at the end of the article
}

The disease occurs in vast geographical regions ranging from the Sahara to the Kalahari Desert [1,3]. Until recently, African trypanosomiasis was receiving very few attentions, and health interventions and research and development were inadequate to the need [4-6].

African animal trypanosomosis (AAT) is also a major constraint to livestock productivity. It has a significant impact on the livelihood of millions of people in Africa and costing several billion US dollars each year [5]. T. congolense, T. vivax and, to a lesser extent T. b. brucei, are the agents of trypanosomosis in livestock [1,7]. In Ethiopia, it has been described as a major impediment to the livestock development and agricultural production [8]. 
The current options for trypanosomiasis treatment are ineffective due to several reasons, making the search for improved drugs essential. Moreover, because those in the lower socioeconomic class are disproportionately affected by the disease, there is a great need for the development of not only less toxic and more effective drugs but also less expensive agents [6,9].

Aloin and its derivatives are found in large amounts in the leaf exudates of several Aloe species of Ethiopia such as Aloe gilbertii T.Reynolds. The investigation of the biological properties of aloin and its semi-synthetic derivatives could prove to be invaluable from a medicinal perspective. Hence, this study was conducted to evaluate the possible antitrypanosomal activity of these plant products which were obtained from the robust and easily cultivatable endemic Aloe species of Ethiopia.

\section{Materials and methods Materials Plant material}

Leaves of A. gilbertii were collected from Oromia region, Shashemene Woreda, Jello Kebele, some $250 \mathrm{~km}$ south of Addis Ababa, Ethiopia. Identification and authentication of the plant were made by Prof. Sebsebe Demissew at the National Herbarium, Department of Biology, Addis Ababa University where a voucher specimen was deposited (collection number AG 001).

\section{Instruments and apparatus}

Homemade silica gel thin layer chromatography (TLC) plates (Merck, Germany) of $0.25 \mathrm{~mm}$ thickness were used for isolation and analytical chromatographic purposes. ${ }^{1} \mathrm{H}$ NMR, ${ }^{13} \mathrm{C}$ NMR spectra were recorded on Bruker Avance DMX400 FT-NMR spectrometer operating at $400 \mathrm{MHz}$ and $100 \mathrm{MHz}$, respectively, at room temperature using deuterated methanol or chloroform. ESI-MS were measured on Ultimate 3000 LC-MS using an electrospray ionization method with negative mode. The source voltage and temperature were fixed at $3 \mathrm{kV}$ and $250^{\circ} \mathrm{C}$.

\section{Test organisms}

$T$. congolense stocks that were originally isolated from a pure natural infection of cattle herd in Arbaminch area, southwest Ethiopia were obtained from School of Veterinary Medicine, Addis Ababa University. The organisms were maintained by serial passages in mice until required.

\section{Experimental animals}

Swiss albino mice of either sex, weighing 25-35 g (age 8-12 weeks) were obtained from the College of Veterinary Medicine and Agricultture, Addis Ababa University. The animals were acclimatized for a period of 7 days at room temperature $23-25^{\circ} \mathrm{C}$ with relative humidity of $60-65 \%$ and allowed free access to pellet diet and water ad libitum. All procedures complied with the Guide for the Care and Use of Laboratory Animals [10] and approved by the Institutional Review Board of the School of Pharmacy, Addis Ababa University.

\section{Methods \\ Preparation of test substances}

Exudate Exudate was collected from the leaves of A. gilbertii by arranging the leaves concentrically around a depression in the soil, which was covered with a plastic sheet. It was then left in open air for 3 days to allow evaporation of water, which yielded a yellow powder.

Aloin The exudate (10 g) was dissolved in methanol, filtered and dried in a rotary evaporator under reduced pressure. The resulting powder was then dissolved in methanolic $\mathrm{HCl}(2 \%)$ and heated to $60^{\circ} \mathrm{C}$ under reflux for $2 \mathrm{~h}$ until a single spot was obtained when monitored by TLC. After removing of the solvent under reduced pressure, the reaction product was subjected to preparative thin layer chromatography (PTLC) over silica gel and developed using chloroform: methanol (4:1) as a solvent system to obtain a yellow amorphous solid $\left[R_{f}=\right.$ $0.35\left(\mathrm{CHCl}_{3} / \mathrm{MeOH}\right.$; 4:1), (-)LR-ESIMS $m / z=417$ [M$\mathrm{H}]^{-}, \mathrm{C}_{21} \mathrm{H}_{21} \mathrm{O}_{9} ;{ }^{1} \mathrm{H}$ NMR (400 MHz, $\left.\mathrm{CDCl}_{3}\right) \delta 11.88$ / 11.85 (1-OH, brs), 11.80/11.78 (8-OH, brs), 7.50/7.57 $(\mathrm{H}-6, t), 7.06 / 7.08(\mathrm{H}-5, d), 7.01 / 7.03(\mathrm{H}-4, d), 6.88 / 6.90$ $(\mathrm{H}-7, d), 6.83 / 6.85(\mathrm{H}-2, d), 4.95 / 4.96(\mathrm{H}-15, s), 4.56 / 4.57$ (H-10, s), 2.72-3.99 (H-1'-H-6'; Glucose). ${ }^{13} \mathrm{C}$ NMR (100 $\left.\mathrm{MHz}, \mathrm{CDCl}_{3}\right) \delta$ 193.82/193.77 (C-9), 161.56 (C-8), 161.33/161.21 (C-1), 152.65/151.82 (C-3), 146.30/146.09 (C-12), 142.47/142.26 (C-14), 136.54/135.67 (C-6), 120.70/ 119.36 (C-5), 118.27/116.67 (C-4), 117.82/117.50 (C-11), 116.26/116.17 (C-13), 116.07/115.84 (C-7), 113.10/112.78 (C-2), 62.86/62.82 (C-15), 44.62/44.32 (C-10), 60.21-85.61 (C-1'-C-6' glucose)] identified as aloin [11].

Aloe-emodin Aloin (about $1 \mathrm{~g}$ ) was added to an acidic solution containing a mixture of $25 \mathrm{ml}$ of concentrated hydrochloric acid and $75 \mathrm{ml}$ of water. $50 \mathrm{ml}$ of a $20 \%$ aqueous solution of ferric chloride were added to the above solution and the resulting mixture was transferred to a round bottom flask. About $30 \mathrm{ml}$ of toluene were added to the above mixture and the biphasic mixture refluxed for $8 \mathrm{~h}$ at $100^{\circ} \mathrm{C}$. The reaction mixture was then allowed to cool to about $90^{\circ} \mathrm{C}$ and the organic layer was separated and kept overnight at $8^{\circ} \mathrm{C}$ to yield aloeemodin [Orange solid crystals, (-)HR-ESIMS $\mathrm{m} / \mathrm{z}=$ $269.0452[\mathrm{M}-\mathrm{H}]^{-}, \mathrm{C}_{15} \mathrm{H}_{9} \mathrm{O}_{5}$, (calc. $\left.=269.0450\right),{ }^{1} \mathrm{H}$ NMR (400 MHz, DMSO- $\left.d_{6}\right): \delta 11.80(1-\mathrm{OH}$ and $8-\mathrm{OH}, b r s)$, $7.70(\mathrm{H}-6, t), 7.65(\mathrm{H}-5, d d), 7.60$ (H-4, brs), 7.30 (H-7, $d d), 7.20(\mathrm{H}-2, b r s), 5.60(11-\mathrm{OH}, b r s), 4.60(\mathrm{H}-11, s)$. ${ }^{13} \mathrm{C}$ NMR (100 MHz, DMSO- $\left.d_{6}\right): 191.37$ (C-9), 181.02 
(C-10), 161.54 (C-8), 161.23 (C-1), 153.62 (C-3), 137.18 (C-6), 133.01 (C-12), 132.77 (C-14), 124.22 (C-7), 120.51 (C-2), 119.19 (C-5), 116.97 (C-4), 115.53 (C-11), 114.08 (C-13), 61.99 (C-15) [12-14].

Rhein Sodium nitrite $(1.275 \mathrm{~g})$ dissolved in $7 \mathrm{ml}$ of conc. sulfuric acid was heated to about $120^{\circ} \mathrm{C}$. Aloeemodin $(0.5 \mathrm{~g})$ was added in small amount to this mixture over a period of $30 \mathrm{~min}$. The reaction was allowed to continue for $5 \mathrm{~h}$ and the reaction mixture poured into ice to give an orange brown precipitate. The precipitate formed was filtered and then dissolved in sodium carbonate solution ( $\mathrm{pH}$ not exceeding 9.5) and extracted with toluene to remove the unreacted aloe-emodin. The aqueous solution was treated with concentrated hydrochloric acid and the precipitate filtered, washed, dried and recrystallized from methanol to obtain a pale yellow powder identified as rhein [(-)HR-ESIMS $m / z=283.0248$ $[\mathrm{M}-\mathrm{H}]^{-}$, (calc. 283.0243), ${ }^{1} \mathrm{H}$ NMR (400 MHz, DMSO$\left.d_{6}\right): \delta 11.95(1-\mathrm{OH}$ and $8-\mathrm{OH}$, brs $), 10.20(11-\mathrm{COOH}$, brs), 8.20 (H-4), 7.75 (H-2), 7.65 (H-6), 7.60 (H-5), 7.40 (H-7)] (Scheme 1) [13,14].

Acute toxicity study Acute toxicity study was carried out using to OECD guideline for testing of chemicals using Swiss albino mice [15]. Twenty-four female Swiss albino mice were randomly divided into 4 groups of 6 mice per cage. Before administration of a single dose of the test substance, the mice were fasted for $2 \mathrm{~h}$ (water allowed) [16]. Each group of mice separately received $2000 \mathrm{mg} / \mathrm{kg}$ of the test substance orally and were observed closely during the first $30 \mathrm{~min}$ after dosing, periodically during the first $24 \mathrm{~h}$ with special attention to the first $4 \mathrm{~h}$ and once daily thereafter for a total of 7 days. The experimental animals were monitored for signs of toxicity such as changes in skin colour, blinking eyes, tremors, convulsion, lacrimation, muscle weakness, sedation, urination, salivation, diarrhoea, lethargy, sleep, coma and death, if any.

\section{In vitro antitrypanosomal activity test}

Assessment of in vitro trypanocidal activity was performed in triplicate in 96 well microtiter plates. Infected mice with high parasitaemic state were sacrificed and the blood collected in EDTA coated syringe prepared with phosphate buffer saline glucose (PBSG). Blood (20 $\mu \mathrm{l})$ containing about 20-25 parasites per field was mixed with $5 \mu \mathrm{l}$ of each of the test substances dissolved in $10 \%$ DMSO in concentrations of 20.0, 10.0, 2.0 and $0.5 \mathrm{mg} /$ $\mathrm{ml}$ to produce effective test concentrations of 4.0, 2.0, 0.4 and $0.1 \mathrm{mg} / \mathrm{ml}$, respectively [17-20]. To a set of controls containing the parasite $(20 \mu \mathrm{l}$ of infected blood $)$ suspended in $10 \%$ DMSO only, and a similar concentration of standard trypanocidal drug diminazene aceturate were included to serve as negative and positive controls, respectively [17,19-21].

After $5 \mathrm{~min}$ incubation in closed microtiter plates maintained at $37^{\circ} \mathrm{C}$, about $20 \mu \mathrm{l}$ of test mixtures were placed on separate microscope slides and covered with $7 \times 22-\mathrm{mm}$ cover slips and the parasites were observed every $5 \mathrm{~min}$ for death/motility for a total duration of one $\mathrm{h}$ using X400 objective.

\section{In vivo infectivity test}

Infectivity test was performed in order to know if there are any remaining parasites after in vitro test which are infective. In this test the inoculum contained each remaining incubation mixture from each well of the micro titer plate where the in vitro test was carried out i.e. 4, 2, 0.4 and $0.1 \mathrm{mg} / \mathrm{ml}$ of test substance separately in $0.02 \mathrm{ml}$ of infected blood as described by Yusuf et al. [6] and Maikai [19]. A total of 105 healthy mice (5 animals per dose) received each mixture intraperitoneally (after 2 $\mathrm{h}$ incubation) and observed for 30 days for the development of infection.

\section{In vivo antitrypanosomal activity test}

Parasite inoculation and test compounds administration

A total of ninety healthy mice were randomly grouped into fifteen groups (A-I, A-II, A-III, B-I, B-II, B-III, C-I,

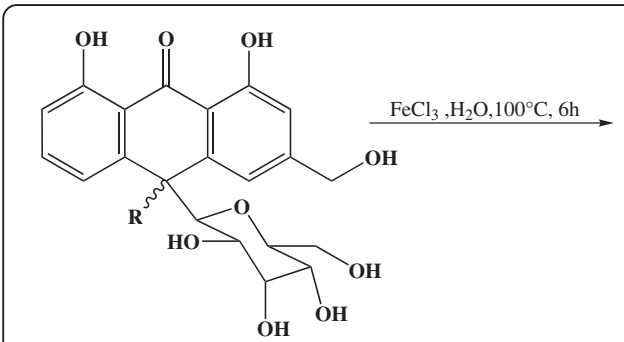

Aloin

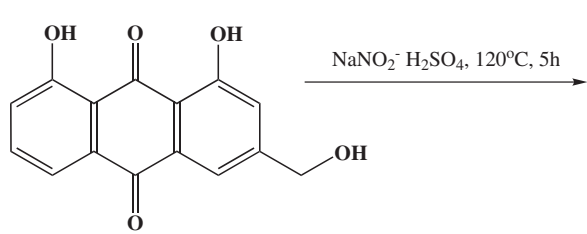

Aloe-emodin<smiles>O=C(O)c1cc(O)c2c(c1)C(=O)c1cccc(O)c1C2=O</smiles>

Rhein

Scheme 1 Oxidative hydrolysis of aloin to aloe-emodin and further oxidation of aloe-emodin to rhein. 
C-II, C-III, D-I, D-II, D-III, and E, F, G) of six mice each. All experimental groups except group $G$ were then infected intraperitoneally with $0.2 \mathrm{ml}$ of infected blood diluted with PBS containing approximately $10^{5}$ trypanosome cells collected from donor mice by cardiac puncture.

The animals were allowed to develop parasitaemia in 14 days, and treatment was initiated on day 15 when parasites were detected and average parasitaemia became approximately 7.20 (log number) $\sim 10^{7.20} / \mathrm{ml}$. Groups A-I, A-II, A-III, B-I, B-II, B-III, C-I, C-II, C-III and D-I, D-II, D-III were injected intraperitoneally 100, 200 and $400 \mathrm{mg} / \mathrm{kg}$ of the leaf exudate, aloin, aloeemodin and rhein, respectively. Dose selection for each group was made after undertaking oral acute toxicity study. The test substances dissolved in 10\% DMSO were administered to the experimental mice every morning for seven days. Group E (positive control group) received $28 \mathrm{mg} / \mathrm{kg}$ (intraperitoneal single dose) of the standard drug diminazene aceturate dissolved and reconstituted in distilled water. Group F (negative control group) were infected with the parasite but not treated, whereas Group G included uninfected-untreated mice for reference purpose e.g. for comparison of some haematological parameters.

\section{Determination of parastaemia}

Parasitaemia was monitored on every other day by microscopic examination of blood obtained from the tail and pre-sterilized with methylated spirit. The degree of parastaemia was determined microscopically at X400 magnification using the "Rapid Matching" method as outlined by Herbert and Lumsden [22]. The method involves microscopic counting of parasites per 1, 5, 10 and 20 fields in pure blood or blood appropriately diluted with PBS (pH 7.2). Wet smear was prepared in triplicate from each animal and the mean value of slide counts was taken per sample examined microscopically. Logarithm values of these counts were obtained by matching with the Table of Herbert and Lumsden [22].

Daily treatment continued for seven days with continuous monitoring of parasitaemia every other day until the $14^{\text {th }}$ day. For the assessment of antitrypanosomal effect of the test compounds, the level of parasitaemia (expressed as log of absolute number of parasites per milliliter of blood) in the treated animals was compared with those of the control animals $[19,23]$.

\section{Determination of packed cell volume (PCV)}

Packed cell volume (PCV) was monitored on days 0,7 and 14 using Wintrobe's method. Heparinised capillary tubes were filled two-thirds to three-quarters with blood obtained by bleeding tail vein of mice and sealed immediately. The tubes were then centrifuged in a microcentrifuge for $5 \mathrm{~min}$ at $10000 \mathrm{rpm}$. After centrifugation, the height of the red blood cell column was measured by the use of haematocrit reader and compared to the total height of the column of the whole blood.

\section{Statistical analysis}

The data were analyzed using Statistical Package for Social Science (SPSS), version 16.0. Values of the data obtained from the study were summarized and expressed as mean \pm standard error of mean (SEM). One way ANOVA followed by Tukey's multiple comparison tests was performed to determine statistical significance. The level of significance for the differences between means within a group and in vitro data were computed by student's $t$ test. P values less than 0.05 were considered significant.

\section{Results and discussion}

The results of acute toxicity study revealed that none of the tested substances possesses adverse reactions like increased motor activity, blinking eyes, tremors, convulsion, lacrimation, stimulation, muscle weakness, sedation, urination, salivation, lethargy, sleep, tremors, arching and rolling and coma up to a dose of $2,000 \mathrm{mg} / \mathrm{kg}$. However, minor signs of toxicity such as temporary hair erection and diarrhoea were observed in two of the experimental animals. This indicates that the test substances are safe at the dose levels used and the $\mathrm{LD}_{50}$ of the test substances are above $2 \mathrm{~g} / \mathrm{kg}$ as per the OECD guideline [15]. Initially, preliminary antitrypanosomal activity screening was conducted by an in vitro method, which is relatively simple, cheap and reliable. As reported previously [17,19,24], under this in vitro system, trypanosomes could survive for up to $4 \mathrm{~h}$ or more in the absence of drugs. Parasites motility constitutes a relatively reliable indicator of viability among most zooflagellate parasites and cessation or drop in motility of the parasites in test substances treated blood compared to that of parasite-loaded control blood without test substances was taken as a measure of trypanocidal activity $[17,20]$. The in vitro test showed that at a concentration of $4.0 \mathrm{mg} / \mathrm{ml}$ the parasites were completely immobilized or killed by incubation with the leaf exudate, aloin, aloe-emodin and rhein within 25, 40, 20 and $15 \mathrm{~min}$, respectively, while the standard drug diminazene aceturate immobilized or eliminated the parasites within $10 \mathrm{~min}$ of incubation at the same concentration (Table 1). The control consisting of trypanosomes incubated with $10 \%$ DMSO showed the presence of very active parasites for more than $1 \mathrm{~h}$. In agreement with previous reports $[21,25,26]$, the present results confirm that compounds with anthraquinone scaffold exhibit in vitro antitrypanosomal activity. Previously, aloe-emodin has been reported to have activity $\left(\mathrm{IC}_{50}=14 \mu \mathrm{M}\right)$ against the bloodstream form of T.b. brucei [27]. According to Atawodi [28], the mean minimum inhibitory concentration (MIC) value of the common trypanocidal drugs is $10.7 \mathrm{mg} / \mathrm{ml}$, and that agents with MIC values of $5-20 \mathrm{mg} / \mathrm{ml}$ could be regarded 
Table 1 Effect of test substances on motility of Trypanosoma congolense

\begin{tabular}{llllll}
\hline Test substance & \multicolumn{3}{l}{$\begin{array}{l}\text { Time (min) after which } \\
\text { motility ceased vs. effective } \\
\text { concentrations }\end{array}$} & \multirow{2}{\text{(mg/ml)}}{$\begin{array}{l}\text { Parasite } \\
\text { motility }\end{array}$} \\
\cline { 2 - 5 } & $\mathbf{4 . 0}$ & $\mathbf{2 . 0}$ & $\mathbf{0 . 4}$ & $\mathbf{0 . 1}$ & \\
\hline Exudate & 25 & 40 & 55 & $>60$ & ++ \\
Aloin & 40 & 60 & $>60$ & $>60$ & + \\
Aloe-emodin & 20 & 40 & 55 & $>60$ & ++ \\
Rhein & 15 & 25 & 45 & $>60$ & +++ \\
Diminazene aceturate & 10 & 20 & 40 & $>60$ & +++ \\
10\% DMSO & $\mathrm{NE}$ & $\mathrm{NE}$ & $\mathrm{NE}$ & $\mathrm{NE}$ & $\mathrm{NE}$ \\
\hline
\end{tabular}

$+++=$ reduced highly,$++=$ reduced moderately,$+=$ reduced slightly, DMSO = dimethyl sulfoxide, $\mathrm{NE}=$ no noticeable effect on motility even after $60 \mathrm{~min}$.

as very active. Therefore, the exudate and pure compounds tested in the present study can be considered as promising antitrypanosomal agents, although their activity was not as strong as that of the positive control diminazene aceturate. However, the activity of the compounds may be increased by structural modification.

It should be noted that in the in vitro model, complete immobility of parasites does not necessarily mean that the parasites are dead, but rather the parasites may have lost their infectivity. This was confirmed through the infectivity test which showed that the test substances inhibited healthy mice from developing infection for more than 30 days or significantly prolonged the prepatent period especially at a concentration of $4.0 \mathrm{mg} / \mathrm{ml}$ (Table 2) unlike the negative control which developed infection within 11 days after inoculation. The test substances may have caused loss of infectivity by abrogating some vital metabolic processes in the parasites or inducing some morphological changes in the parasites that render them more susceptible to the mice immune defense systems. In the present in vivo study, there was a reduction in parasitaemia following administration of the leaf exudate as well as the pure compounds. The results confirmed that all the test substances possess mild to moderate antitrypanosomal activity in vivo, but did not completely clear the parasite. The inability of the test substances to clear the parasite from the blood could be because of their failure to reach the site of action or rapid metabolization [29]. Though parasitaemia was not completely eliminated, rhein was found to be the most active of all the substances tested (Table 3). Also, at a dose of $400 \mathrm{mg} / \mathrm{kg}$ the leaf exudate of A. gilbertii, reduced parasitaemia level significantly.

From the results of the present study it is not possible to know the mechanism (s) by which the test substances exert their antitrypanosomal activity. However, accumulated evidence $[25,28]$ suggests that many natural products which contain anthraquinone scaffold exhibit their
Table 2 Duration (days) after which parasitaemia developed in mice inoculated with a mixture of test substances and Trypanosoma congolense infected blood

\begin{tabular}{lll}
\hline $\begin{array}{l}\text { Dose of test substance } \\
\text { mixed with 0.02 ml } \\
\text { of infected blood }\end{array}$ & $\begin{array}{l}\text { Number of mice } \\
\text { which developed } \\
\text { infection }\end{array}$ & $\begin{array}{l}\text { Infection interval } \\
\text { in days (mean } \pm \text { SEM) }\end{array}$ \\
\hline $4.0 \mathrm{mg} / \mathrm{ml} \mathrm{E}$ & $0 / 5$ & $\mathrm{Ni}$ \\
$2.0 \mathrm{mg} / \mathrm{ml} \mathrm{E}$ & $2 / 5$ & $17.50 \pm 0.50$ \\
$0.4 \mathrm{mg} / \mathrm{ml} \mathrm{E}$ & $4 / 5$ & $13.75 \pm 0.48$ \\
$0.1 \mathrm{mg} / \mathrm{ml} \mathrm{E}$ & $5 / 5$ & $12.20 \pm 0.40$ \\
$4.0 \mathrm{mg} / \mathrm{ml} \mathrm{A}$ & $1 / 5$ & 26.00 \\
$2.0 \mathrm{mg} / \mathrm{ml} \mathrm{A}$ & $3 / 5$ & $16 \pm 0.58$ \\
$0.4 \mathrm{mg} / \mathrm{ml} \mathrm{A}$ & $5 / 5$ & $13.40 \pm 0.24$ \\
$0.1 \mathrm{mg} / \mathrm{ml} \mathrm{A}$ & $5 / 5$ & $11.80 \pm 0.66$ \\
$4.0 \mathrm{mg} / \mathrm{ml} \mathrm{AE}$ & $0 / 5$ & $\mathrm{Ni}$ \\
$2.0 \mathrm{mg} / \mathrm{ml} \mathrm{AE}$ & $2 / 5$ & $18.00 \pm 1.00$ \\
$0.4 \mathrm{mg} / \mathrm{ml} \mathrm{AE}$ & $4 / 5$ & $14.00 \pm 0.40$ \\
$0.1 \mathrm{mg} / \mathrm{ml} \mathrm{AE}$ & $5 / 5$ & $12.00 \pm 0.54$ \\
$4.0 \mathrm{mg} / \mathrm{ml} \mathrm{Rx}$ & $0 / 5$ & $\mathrm{Ni}$ \\
$2.0 \mathrm{mg} / \mathrm{ml} \mathrm{Rx}$ & $2 / 5$ & $19.50 \pm 0.71$ \\
$0.4 \mathrm{mg} / \mathrm{ml} \mathrm{Rx}$ & $3 / 5$ & $17.00 \pm 0.58$ \\
$0.1 \mathrm{mg} / \mathrm{ml} \mathrm{Rx}$ & $5 / 5$ & $14.20 \pm 0.37$ \\
$4.0 \mathrm{mg} / \mathrm{ml} \mathrm{DA}$ & $0 / 5$ & $\mathrm{Ni}$ \\
$2.0 \mathrm{mg} / \mathrm{ml} \mathrm{DA}$ & $1 / 5$ & 19.00 \\
$0.4 \mathrm{mg} / \mathrm{ml} \mathrm{DA}$ & $3 / 5$ & $16.33 \pm 0.33$ \\
$0.1 \mathrm{mg} / \mathrm{ml} \mathrm{DA}$ & $5 / 5$ & $13.40 \pm 0.81$ \\
$0.1 \mathrm{ml} 10 \%$ DMSO & $5 / 5$ & $11.20 \pm 0.49$ \\
\hline & &
\end{tabular}

$\mathrm{N}=5, \mathrm{Ni}=$ no infection developed in the observation period, $\mathrm{E}=$ leaf exudate of Aloe gilbertii, $\mathrm{A}=$ aloin, $\mathrm{AE}=$ aloe-emodin, $\mathrm{Rx}=$ rhein, $\mathrm{DA}=$ diminazene aceturate, $\mathrm{DMSO}=$ dimethylsulfoxide, $\mathrm{SEM}=$ standard error of mean.

antitrypanosomal activity by virtue of their interference with the redox balance of the parasites acting either on the respiratory chain or on the cellular defenses against oxidative stress. This is because anthraquinones are capable of generating radicals that may cause peroxidative damage to trypanothione reductase that is very sensitive to alterations in redox balance.

The experiment on PCV analysis also gave results that were consistent with the observations made on parasitaemia levels. Anaemia is the most outstanding clinical and laboratory feature of African trypanosomiasis and also the primary cause of death. Anaemia as indicated by PCV level is known to worsen with increasing parasitaemia [30]. As shown in Table 4, the PCV at days 7 and 14 of mice treated with 400,200 and $100 \mathrm{mg} / \mathrm{kg}$ of rhein was on average above $45 \%$, which was within the range of reference values (42-52\%). Similarly the PCV of animals treated with $400 \mathrm{mg} / \mathrm{kg}$ of the other test substances was found to be above $46 \%$ after 14 days of treatment which is significantly different $(P<0.05)$ when compared 
Table 3 Effect of test substances on parasitaemia level of Trypanosoma congolense infected mice

\begin{tabular}{|c|c|c|c|c|c|c|c|c|c|}
\hline \multirow[t]{2}{*}{ Test substance } & \multirow[t]{2}{*}{ Dose $(\mathrm{mg} / \mathrm{kg})$} & \multicolumn{8}{|c|}{ Trypanosomes $/ \mathrm{ml}^{\mathrm{a}}$} \\
\hline & & Do & D2 & D4 & D6 & D8 & D10 & D12 & D14 \\
\hline \multirow[t]{3}{*}{ Exudate } & 100 & $7.76 \pm 0.02$ & $7.84 \pm 0.06$ & $8.00 \pm 0.09$ & $7.96 \pm 0.08$ & $7.18 \pm 0.38$ & $7.64 \pm 0.12$ & $7.76 \pm 0.18$ & $8.18 \pm 0.09$ \\
\hline & 200 & $7.50 \pm 0.10$ & $7.90 \pm 0.08$ & $7.80 \pm 0.06$ & $7.14 \pm 0.24$ & $6.06 \pm 0.11$ & $7.06 \pm 0.29$ & $7.56 \pm 0.15$ & $7.82 \pm 0.15$ \\
\hline & 400 & $7.46 \pm 0.09$ & $7.86 \pm 0.10$ & $7.90 \pm 0.15$ & $4.92 \pm 1.23^{b}$ & $3.84 \pm 0.90^{b}$ & $4.56 \pm 1.20^{b}$ & $4.80 \pm 0.15^{b}$ & $5.44 \pm 0.37$ \\
\hline \multirow[t]{3}{*}{ Aloin } & 100 & $7.34 \pm 0.06$ & $7.70 \pm 0.13$ & $7.96 \pm 0.08$ & $8.07 \pm 0.07$ & $7.54 \pm 0.21$ & $7.70 \pm 0.14$ & $7.80 \pm 0.18$ & $8.19 \pm 0.08$ \\
\hline & 200 & $7.74 \pm 0.05$ & $7.94 \pm 0.06$ & $7.86 \pm 0.05$ & $7.40 \pm 0.29$ & $6.60 \pm 0.32$ & $7.10 \pm 0.27$ & $7.82 \pm 0.18$ & $7.83 \pm 0.13$ \\
\hline & 400 & $7.38 \pm 0.09$ & $7.95 \pm 0.14$ & $7.97 \pm 0.11$ & $5.24 \pm 1.40$ & $4.38 \pm 1.09^{b}$ & $5.62 \pm 1.50$ & $5.98 \pm 0.15$ & $6.02 \pm 0.49$ \\
\hline \multirow[t]{3}{*}{ Aloe-emodin } & 100 & $7.48 \pm 0.09$ & $7.72 \pm 0.73$ & $7.96 \pm 0.05$ & $8.14 \pm 0.17$ & $7.57 \pm 0.19$ & $7.75 \pm 0.08$ & $7.82 \pm 0.17$ & $8.20 \pm 0.05$ \\
\hline & 200 & $7.42 \pm 0.07$ & $7.92 \pm 0.03$ & $7.88 \pm 0.03$ & $7.48 \pm 0.30$ & $6.77 \pm 0.27$ & $7.36 \pm 0.20$ & $7.76 \pm 0.16$ & $7.97 \pm 0.17$ \\
\hline & 400 & $7.37 \pm 0.08$ & $7.90 \pm 0.15$ & $8.00 \pm 0.13$ & $5.38 \pm 1.42$ & $4.56 \pm 1.14^{b}$ & $6.04 \pm 1.52$ & $6.74 \pm 0.13$ & $6.90 \pm 0.38$ \\
\hline \multirow[t]{3}{*}{ Rhein } & 100 & $7.23 \pm 0.18$ & $7.29 \pm 0.27$ & $6.49 \pm 0.30$ & $5.58 \pm 0.40$ & $4.92 \pm 1.53$ & $4.22 \pm 1.56$ & $5.21 \pm 0.37$ & $5.57 \pm 1.51$ \\
\hline & 200 & $7.41 \pm 0.08$ & $6.97 \pm 0.33$ & $5.32 \pm 1.37$ & $5.24 \pm 1.35$ & $3.66 \pm 1.51^{b}$ & $4.10 \pm 0.27^{b}$ & $4.82 \pm 0.18^{b}$ & $4.83 \pm 0.13^{b}$ \\
\hline & 400 & $7.41 \pm 0.08$ & $7.00 \pm 0.25$ & $4.88 \pm 1.28^{b}$ & $3.66 \pm 1.50^{b}$ & $2.34 \pm 1.44^{b}$ & $2.22 \pm 1.45^{\mathrm{b}}$ & $2.96 \pm 0.33^{b}$ & $3.22 \pm 0.25^{b}$ \\
\hline Deminazene aceturate & 28 & $7.35 \pm 0.08$ & $0.00 \pm 0.00$ & $0.00 \pm 0.00$ & $0.00 \pm 0.00$ & $0.00 \pm 0.00$ & $0.00 \pm 0.00$ & $1.08 \pm 1.08$ & $1.97 \pm 1.36$ \\
\hline Distilled water & $0.1 \mathrm{ml}$ & $7.43 \pm 0.10$ & $8.10 \pm 0.08$ & $8.60 \pm 0.08$ & $8.65 \pm 0.13$ & $8.71 \pm 0.06$ & $9.36 \pm 0.20$ & $8.94 \pm 0.03$ & $8.72 \pm 0.34$ \\
\hline
\end{tabular}

${ }^{\mathrm{a}}$ The antilog values of the numbers indicated in the table give the absolute number of trypanosomes/ml of blood; ${ }^{\mathrm{b}} \mathrm{Significantly} \mathrm{different}$ when compared with the negative control $(P<0.05)$; Values are Mean $\pm \mathrm{SEM} ; \mathrm{N}=6$; $\mathrm{D}=$ day; $\mathrm{D} 0=$ the day treatment commenced; $\mathrm{SEM}=\mathrm{standard}$ error of mean.

Table 4 Effect of test substances on packed cell volume (PCV) of Trypanosma congolense infected mice

\begin{tabular}{|c|c|c|c|c|}
\hline \multirow[t]{2}{*}{ Treatment } & \multirow{2}{*}{$\begin{array}{l}\text { Dose } \\
(\mathrm{mg} / \mathrm{kg})\end{array}$} & \multicolumn{3}{|c|}{ PCV/Day of treatment } \\
\hline & & PCV0 & PCV7 & PCV14 \\
\hline \multirow[t]{3}{*}{ Exudate } & 100 & $47.10 \pm 0.68$ & $42.40 \pm 1.07^{\mathrm{bc}}$ & $45.10 \pm 0.91^{a}$ \\
\hline & 200 & $48.30 \pm 1.11$ & $44.00 \pm 1.50^{b}$ & $48.20 \pm 0,46^{a}$ \\
\hline & 400 & $47.00 \pm 1.21$ & $43.60 \pm 1.41^{b}$ & $47.60 \pm 1.44^{\mathrm{a}}$ \\
\hline \multirow[t]{3}{*}{ Aloin } & 100 & $46.40 \pm 1.53$ & $40.00 \pm 1.87^{b c}$ & $42.70 \pm 1.21^{b c}$ \\
\hline & 200 & $46.00 \pm 1.17$ & $40.60 \pm 1.22^{b c}$ & $43.90 \pm 0.66^{b c}$ \\
\hline & 400 & $45.50 \pm 1.50$ & $41.70 \pm 1.21^{b c}$ & $46.20 \pm 1.34^{a}$ \\
\hline \multirow[t]{3}{*}{ Aloe-emodin } & 100 & $50.20 \pm 1.20$ & $44.20 \pm 1.65^{b}$ & $47.20 \pm 0.73^{a}$ \\
\hline & 200 & $47.90 \pm 0.60$ & $44.30 \pm 0.80^{b}$ & $46.10 \pm 0.87^{a}$ \\
\hline & 400 & $47.10 \pm 0.57$ & $45.90 \pm 1.45^{\mathrm{b}}$ & $47.30 \pm 0.73^{a}$ \\
\hline \multirow[t]{3}{*}{ Rhein } & 100 & $47.10 \pm 0.64$ & $45.40 \pm 0.76^{b}$ & $47.20 \pm 0.25^{a}$ \\
\hline & 200 & $50.00 \pm 0.65$ & $45.80 \pm 0.46^{\mathrm{b}}$ & $49.30 \pm 0.41^{\mathrm{a}}$ \\
\hline & 400 & $50.20 \pm 1,10$ & $48.00 \pm 1.15$ & $50.40 \pm 0.73^{a}$ \\
\hline $\begin{array}{l}\text { Diminazene } \\
\text { aceturate }\end{array}$ & 28 & $50.10 \pm 0.33$ & $48.60 \pm 0.57$ & $50.60 \pm 0.43^{\mathrm{a}}$ \\
\hline Distilled water & $0.1 \mathrm{ml}$ & $46.00 \pm 0.79$ & $42.10 \pm 1.18^{b c}$ & $40.10 \pm 1.10^{*}$ \\
\hline $\begin{array}{l}\text { Uninfected } \\
\text { untreated }\end{array}$ & - & $50.50 \pm 0.59$ & $51.10 \pm 0.66$ & $50.80 \pm 0.67$ \\
\hline
\end{tabular}

Values are Mean $\pm \mathrm{SEM}, \mathrm{N}=6, \mathrm{D}=$ day, $\mathrm{PCV} 0=\mathrm{PCV}$ on the day treatment commenced, $\mathrm{SEM}=$ standard error of mean. All superscripts indicate significance at $P<0.05$ (against negative control, bagainst uninfected-untreated, cagainst $28 \mathrm{mg} / \mathrm{kg}$ diminazene aceturate, ${ }^{*}$ against all groups), PCV was compared with each other mainly at days 7 and 14 . to the negative control. This improvement of PCV may be due to reduction of the parasitaemia level or neutralizing the toxic metabolites produced by trypanosomes after treatment.

\section{Conclusion}

The results of the present study revealed that the leaf exudate of $A$. gilbertii as well as the pure compounds tested, namely aloin, aloe-emodin, and rhein possess mild to moderate antitrypanosomal activity both in vitro and in vivo against $T$. congolense field isolate. More importantly, the work confirmed that the two anthraquinones, namely aloe-emodin and rhein, particularly the latter, possess a much better activity than aloin which contains the anthrone moiety. Thus, the promising activity profile of the anthraquinones tested along with their relative margin of safety merit the use of these compounds as leads for the development of safer, more potent and cost effective alternative drugs for the treatment of African trypanosomiasis.

\section{Competing interests}

The authors declare that they have no competing interests.

\section{Authors' contributions}

YT: Collected plant material, carried out the experimental work and drafted the manuscript. DB: Assisted in the extraction, isolation, preparation and identification of compounds including interpretation of spectral data. GT: Designed experiments for both in vitro and in vivo antitrypanosomal activity testing. KA: Involved in the isolation and preparation of compounds, corrected, edited and proof read the manuscript before submission. All authors read and approved the final manuscript. 


\section{Acknowledgements}

The authors are grateful to Prof. Sebsebe Demissew for identification and authentication of the plant material. One of the authors (Y.T.) would like to acknowledge the office of the Vice President for Research and Dean of Graduate Studies of Addis Ababa University for sponsoring this study and Jigjiga University for granting study leave.

\section{Author details}

'Department of Pharmaceutical Chemistry and Pharmacognosy, School of Pharmacy, Addis Ababa University, Addis Ababa, Ethiopia. ${ }^{2}$ Department of Pathology and Parasitology, College of Veterinary Medicine and Agriculture, Addis Ababa University, Debre Zeit, Ethiopia.

Received: 6 December 2013 Accepted: 5 March 2014

Published: 10 March 2014

\section{References}

1. Pascal G, Paul C, Jean-Paul B, Edith D, Géraldine S, Patrick J, Philippe V, Zakaria B, Alain B, Gérard C, Philippe H: Identification of total and differentially expressed excreted-secreted proteins from Trypanosoma congolense strains exhibiting different virulence and pathogenicity. Int J Parasitol 2009, 39:1137-1150.

2. Lima FM, Oliveira P, Mortara RA, Silveira JF, Bahia D: The challenge of chagas'disease: has the human pathogen, Trypanosome cruzi, learned how to modulate signaling events to subvert host cells? J New Biotechnol 2010, 27:837-844.

3. Oumarou F, Flobert N, Jean MA, Guy NR, Hugues ND, Tazoacha A, Pere SP, Gérard C, Anne G: Tripartite interactions between tsetse flies, Sodalis glossinidius and trypanosomes an epidemiological approach in two historical human African trypanosomiasis foci in Cameroon. J Inf Gen Evol 2010, 10:115-121.

4. David H, Richard MC: Molecular mechanisms underlying the control of antigenic variation in African trypanosomes. Curr Opin Microbiol 2010, 13:700-705

5. Etet PFS, Mahomoodally MF: New insights in staging and chemotherapy of African trypanosomiasis and possible contribution of medicinal plants. Scientific World Journal 2012, 2012:343652.

6. Yusuf $A B$, Umar IA, Musa UB, Nok AJ: Screening of Vernonia amygdalina and Hymenocardia acida extracts and 1,3-diaminopropane for their antitrypanosomal activities: In vitro model. J Med Plants Res 2012, 6:3573-3578.

7. Chaka H, Abebe G: Drug resistant trypanosomes: a threat to cattle production in the Southwest of Ethiopia. Elev Med Vet Pays Trop 2003 56:33-36.

8. Seyoum Z, Terefe $\mathrm{G}$, Ashenafi $\mathrm{H}$ : Farmers' perception of impacts of bovine trypanosomosis and tsetse fly in selected districts in Baro-Akobo and Gojeb river basins, Southwestern Ethiopia. BMC Vet Res 2013, 9:214.

9. Kazuhiko O, Masato I, Aki I, Miyuki N, Aki N, Hiroaki K, Toshihiro H, Yoshinori A Satoshi O, Haruki Y: In vitro antitrypanosomal activity of some phenolic compounds from propolis and lactones from Fijian Kawa (Piper methysticum). J Nat Med 2012, 66:558-561.

10. Institute of Laboratory Animal Resources: Guide for the Care and Use of Laboratory Animals. 7th edition. Washington DC: National Academy Press; 1996.

11. Rauwald HW, Lohse K, Bats JW: Configurations of aloin A and B. Two diastereomeric C-glucosylanthrones from Aloe species. Angew Chem Int ed Engl 1989, 28:1528-1529.

12. Conner JM, Gray Al, Waterman PG, Reynolds T: Novel anthrone anthraquinone dimers from Aloe elgonica. J Nat Prod 1990, 53:1362-1364.

13. Alemayehu G, Abegaz B, Snatzke G, Duddeck H: Quinones of Senna didymobotrya. Bull Chem Soc Ethiop 1989, 3:37-40.

14. Danielsen K, Aksens DW, Francis GW: NMR study of some anthraquinones from rhubarb. Magn Reson Chem 1992, 30:359-360.

15. OECD: Acute oral toxicity up and down procedure. OECD Guideline for testing of chemicals, vol. 425. Adopted 17 December 2001.

16. Center for Drug Evaluation and Research (CDER): Guidance for industry single dose acute toxicity testing for chemicals. 1996

17. Atawodi SE, Bulus T, Ibrahim S, Ameh DA, Nok AJ, Mamman M, Galadima M: In vitro trypanocidal effect of methanolic extract of some Nigerian savannah plants. Afr J Biotechol 2003, 2:317-321.
18. Maikai VA, Nok AJ, Adaudi AO, Alawa C: In vitro antitrypanosomal activity of aqueous and methanolic crude extracts of stem bark of Ximenia americana on Trypanosoma congolense. Afr J Biotechnol 2007, 2:55-58.

19. Maikai VA: Antitrypanosomal activity of flavonoid extracted from Ximenia americana stem bark. Int J Biol 2011, 1:115-121.

20. Peter S, Nandal PN, Prakash SO, Rao J, Kumar SR: In vitro antitrypanosomal evaluation of Picrorhiza kurroa rhizomes. Int Res J Pharm 2012, 3:205-208.

21. Atawodi SE, Ogunbusola F: Evaluation of antitrypanosomal properties of four extracts of leaves, stem and root barks of Prosopis africana in laboratory animals. Nig Soci Exp Biol 2009, 21:101-108.

22. Herbert WJ, Lumsden WHR: Trypanosoma brucei: a rapid matching method for estimating the host parasitaemia. Exp Parasitol 1976, 40:427-431.

23. Ogoti P, Esther M, Joanna A, Gabriel M, Mabel I, Grace M: Evaluation of in vivo antitrypanosomal activity of selected medicinal plant extracts. J Med Plant Res 2009, 3:850-854.

24. Johnson TO, ljeoma KO, Ekanem EE, Nelson E, Mohammed B: In vitro studies on the trypanocidal activities of various phytochemical fractions obtained from Garcinia kola seed. J Med Trop 2011, 13:124-128.

25. Nok AJ: Azanthraquinone inhibits respiration and in vitro growth of long slender blood stream forms of Trypanosoma congolense. Cell Biochem Funct 2002, 20:205-212.

26. Maikai VA, Kobo PI: Preliminary studies on the in vitro antitrypanosomal activity of aqueous and methanolic crude extracts of stem bark of Nauclea latifolia on Trypanosoma congolense. J Med Plant Res 2008, 2:115-118.

27. Hoet S, Opperdoes F, Brun R, Adjakidje V, Quetin L, Eclercq J: In vitro antitrypanosomal activity of ethnopharmacologically selected Beninese plants. J Ethnopharmacol 2004, 91:37-42.

28. Atawodi SE: Phytochemical and antitrypanosomal studies of different solvents extracts of Boswellia dalzielii. Int J Biol 2011, 2:177-182.

29. Wurochekke AU, Anyanwu GO: Antitrypanosomal activity of Anogeissus leiocarpus in rats infected with Trypanosoma brucei brucei. Int J Biotechnol 2011, 3:6-9

30. Abubakar A, lliyasu B, Yusuf AB, Igweh AC, Onyekwelu NA, Shamaki BU, Afolayan DA, Ogbadoyi EO: Antitrypanosomal and haematological effects of selected Nigerian medicinal plants in Wistar rats. Biokemistri 2005, 17:95-99.

\section{doi:10.1186/1746-6148-10-6}

Cite this article as: Tewabe et al.: Antitrypanosomal activity of aloin and its derivatives against Trypanosoma congolense field isolate. BMC Veterinary Research 2014 10:61.

\section{Submit your next manuscript to BioMed Central and take full advantage of:}

- Convenient online submission

- Thorough peer review

- No space constraints or color figure charges

- Immediate publication on acceptance

- Inclusion in PubMed, CAS, Scopus and Google Scholar

- Research which is freely available for redistribution 